OPEN ACCESS

Edited by:

Chiara Bonini,

Vita-Salute San Raffaele University,

Italy

Reviewed by:

Sistiana Aiello,

Istituto di Ricerche Farmacologiche Mario Negri (IRCCS), Italy

Beatrice Claudia Cianciotti,

San Raffaele Hospital (IRCCS), Italy

*Correspondence:

Wenhao Chen

wchen@houstonmethodist.org

Specialty section:

This article was submitted to Alloimmunity and Transplantation,

a section of the journal

Frontiers in Immunology

Received: 15 June 2021 Accepted: 11 August 2021 Published: 26 August 2021

Citation:

Gonzalez NM, Zou D, Gu A and Chen W (2021) Schrödinger's

$T$ Cells: Molecular Insights Into

Stemness and Exhaustion.

Front. Immunol. 12:725618. doi: 10.3389/fimmu.2021.725618

\section{Schrödinger's T Cells: Molecular Insights Into Stemness and Exhaustion}

\author{
Nancy M. Gonzalez ${ }^{1,2}$, Dawei Zou ${ }^{1}$, Andy $G^{1}{ }^{1}$ and Wenhao Chen ${ }^{1,3 *}$ \\ 1 Immunobiology \& Transplant Science Center, Department of Surgery, Houston Methodist Research Institute \& Institute for \\ Academic Medicine, Houston Methodist Hospital, Houston, TX, United States, ${ }^{2}$ College of Medicine, Texas A\&M Health \\ Science Center, College Station, TX, United States, ${ }^{3}$ Department of Surgery, Weill Cornell Medicine, Cornell University, \\ New York, NY, United States
}

T cell stemness and exhaustion coexist as two key contrasting phenomena during chronic antigen stimulation, such as infection, transplant, cancer, and autoimmunity. T cell exhaustion refers to the progressive loss of effector function caused by chronic antigen exposure. Exhausted $T\left(T_{E X}\right)$ cells highly express multiple inhibitory receptors and exhibit severe defects in cell proliferation and cytokine production. The term $T$ cell stemness describes the stem cell-like behaviors of T cells, including self-renewal, multipotency, and functional persistence. It is well accepted that naïve and some memory $T$ cell subsets have stem cell-like properties. When investigating the exhaustive differentiation of $T$ cells in chronic infection and cancer, recent studies highlighted the stemness of "precursors of exhausted" $T\left(T_{P E X}\right)$ cells prior to their terminal differentiation to $T_{E X}$ cells. Clinically successful checkpoint blockades for cancer treatment appear to invigorate antitumor $T_{P E X}$ cells but not $T_{E X}$ cells. Here we discuss the transcriptional and epigenetic regulations of $T$ cell stemness and exhaustion, with a focus on how systems immunology was and will be utilized to define the molecular basis underlying the transition of $T_{P E X}$ to $T_{E X}$ cells. We suggest a "stepwise model" of T cell stemness and exhaustion, in which loss of stemness and exhaustion progression are gradual multi-step processes. We provide perspectives on the research needed to define $T$ cell stemness and exhaustion in the transplantation setting, in which allogenic T cells are also chronically exposed to alloantigens. A better understanding of $T$ cell stemness and exhaustion will shed light on developing novel strategies for immunotherapies.

Keywords: $\mathrm{T}$ cell, $\mathrm{T}$ cell exhaustion, $\mathrm{T}$ cell stemness, transplantation, transcription factor, epigenetic regulation

\section{INTRODUCTION}

The adaptive immune system confers an evolutionary advantage to vertebrates with its highly tailored defense against a myriad of environmental pathogens. During acute infections, naïve T cells of the adaptive immune system are activated in an antigen-specific manner and expand into large numbers of effector T cells. Following the clearance of pathogens, most activated $\mathrm{T}$ cells die, but a small portion develop into memory T cells. Naïve and memory T cells behave somewhat like stem cells. Naïve and memory $\mathrm{T}$ cells for a given antigen are capable of self-renewing in the absence of antigen, persist in low 
abundance in the body, and replenish functional effector cells upon antigen (re-)encounter. The term "T cell stemness" is used to describe stem cell-like behaviors of naïve and memory T cells $(1,2)$.

Chronic infections occur when the host immune system fails to clear the pathogens. In this context, antigen-specific $\mathrm{T}$ cells gradually develop into a dysfunctional cell state termed $\mathrm{T}$ cell exhaustion. Exhausted $\mathrm{T}\left(\mathrm{T}_{\mathrm{EX}}\right)$ cells express high levels of inhibitory receptors (e.g., PD-1, TIM-3, LAG-3, TIGIT), progressively lose cytokine production (e.g., IFN- $\gamma$, TNF- $\alpha$ ) and proliferative capacity, and have a very limited ability to control infections. Recent advances in systems immunology have opened a new avenue for defining $\mathrm{T}$ cell states in diseases. Single-cell sequencing technologies have often identified $\mathrm{T}_{\mathrm{EX}}$ cells in various kinds of solid tumors. T cell exhaustion has thus been recognized as an underlying principle of $\mathrm{T}$ cell dysfunction in both chronic infection and cancer (3).

The PD-L1-PD-1 checkpoint blockade has now become a pillar of cancer therapy. PD-L1-PD-1 blockade was thought to promote antitumor immunity by reversing exhaustion of PD- ${ }^{+} \mathrm{T}$ cells. Using systems immunology to study how PD-L1-PD-1 blockade works, researchers found that terminally differentiated $\mathrm{TCF}^{-}{ }^{-} \mathrm{PD}-1^{+} \mathrm{T}_{\mathrm{EX}}$ cells represent an irreversible $\mathrm{T}$ cell state, and that PD-L1-PD-1 blockade promotes antitumor immunity mainly by invigorating $\mathrm{TCF} 1^{+} \mathrm{PD}-1^{+}$"precursors of exhausted" $\mathrm{T}$ cells ( $\mathrm{T}_{\mathrm{PEX}}$ ) (3). We now know that $\mathrm{T}_{\mathrm{PEX}}$ cells have memory-like properties and maintain aspects of $\mathrm{T}$ cell stemness. $\mathrm{T}_{\mathrm{PEX}}$ cells not only continuously generate $\mathrm{T}_{\mathrm{EX}}$ cells during chronic antigen exposure, but also give rise to functional $\mathrm{T}$ cells and sustain chronic $\mathrm{T}$ cell response even in the absence of checkpoint blockade. Hence, $\mathrm{T}$ cell stemness and exhaustion, two seemly contrasting phenomena, coexist during chronic antigen stimulation.

In this review article, we present an overview of characteristics and the molecular basis of $\mathrm{T}$ cell stemness and exhaustion. We provide a fundamental concept that $\mathrm{T}$ cell stemness and exhaustion together determine the magnitude of chronic $\mathrm{T}$ cell response. Currently, $\mathrm{T}$ cell stemness and exhaustion are far less studied in the transplantation setting compared with those in chronic infection and cancer research. We highlight this research gap for discussion. Systems immunology approaches are timely and highly relevant to characterizing how $\mathrm{T}$ cell stemness and exhaustion together determine transplant outcomes.

\section{STEMNESS OF MEMORY T CELLS}

Adaptive immunity hinges on creating immunological memory after natural acute infection or vaccination. Generating longlived antigen-specific memory lymphocytes forms the cellular basis of immunological memory, which has been extensively studied and reviewed $(4,5)$. Here we discuss the concept of T cell stemness as a basic mechanism that maintains $\mathrm{T}$ cell memory. $\mathrm{T}$ cell stemness encompasses the capacity of a T cell to self-renew as well as to differentiate into multiple downstream cell types, an ability called multipotency.

Early studies examining memory $\mathrm{T}$ cells in mice identified $\mathrm{CD}_{2} \mathrm{~L}^{+} \mathrm{CD} 44^{+}$central memory $\mathrm{T}\left(\mathrm{T}_{\mathrm{CM}}\right)$ and $\mathrm{CD}_{2} \mathrm{~L}^{-} \mathrm{CD} 44^{+}$ effector memory $\mathrm{T}\left(\mathrm{T}_{\mathrm{EM}}\right)$ cells. $\mathrm{T}_{\mathrm{CM}}$ cells are less terminally differentiated than $\mathrm{T}_{\mathrm{EM}}$ cells. Graef et al. have investigated the self-renewal capacity and multipotency of individual $\mathrm{CD}^{+} \mathrm{T}_{\mathrm{CM}}$ cells. In their experimental approach, only one single antigenspecific naïve $\mathrm{T}$ or $\mathrm{T}_{\mathrm{CM}}$ cell was adoptively transferred to each host. They found that the transferred single naïve $\mathrm{T}$ cells and single $\mathrm{T}_{\mathrm{CM}}$ cells produced remarkably similar progeny size and diversity in response to antigen stimulation. Moreover, progeny derived from single primary $\mathrm{T}_{\mathrm{CM}}$ cells contained secondary $\mathrm{T}_{\mathrm{CM}}$ cells. When secondary $\mathrm{T}_{\mathrm{CM}}$ cells were individually transferred to new hosts and exposed to antigen, they again generated a diverse offspring cells, including effector $\mathrm{T}\left(\mathrm{T}_{\mathrm{EFF}}\right), \mathrm{T}_{\mathrm{CM}}$, and $\mathrm{T}_{\mathrm{EM}}$ cells (2). This study elegantly revealed the stemness of naïve and $\mathrm{T}_{\mathrm{CM}}$ cells.

There is a naive-like memory $\mathrm{T}$ cell population even less differentiated than $\mathrm{T}_{\mathrm{CM}}$ cells. These cells were designated memory stem $\mathrm{T}$ cells $\left(\mathrm{T}_{\mathrm{SCM}}\right)$ to reflect their enhanced capacity for self-renewal and multipotent capacity to differentiate into all memory and effector $\mathrm{T}$ cell subsets $(6-8)$. $\mathrm{T}_{\mathrm{SCM}}$ cells bear many similarities to naive $\mathrm{T}$ cells, such as $\mathrm{CD} 62 \mathrm{~L}^{+} \mathrm{CD} 44^{-}$in mice and $\mathrm{CD} 4 \mathrm{RO}^{-} \mathrm{CD} 45 \mathrm{RA}^{+} \mathrm{CD} 62 \mathrm{~L}^{+} \mathrm{IL}-7 \mathrm{R}^{+}$in human. However, they are generated after antigen stimulation and express elevated levels of Bcl-2, Sca-1, IL-2R $\beta$, CXCR3, and CD95 $(6,9)$.

$\mathrm{T}_{\mathrm{SCM}}$ cells develop directly from naïve $\mathrm{T}$ cells. Cieri et al. discovered that IL-7 is critical for the development of human $\mathrm{T}_{\mathrm{SCM}}$ cells from naïve $\mathrm{T}$ cells ex vivo, whereas IL-15 supports their expansion. IL-7/IL-15-instructed and gene-modified $\mathrm{T}_{\mathrm{SCM}}$ cells surpass other memory $\mathrm{T}$ cell subsets for the ability to expand and differentiate into $\mathrm{T}_{\mathrm{EFF}}$ cells, as well as to mediate severe xenogeneic GVHD upon adoptive transfer into immunodeficient mice (10). These findings not only reveal the biologic requirements for $\mathrm{T}_{\mathrm{SCM}}$ cell development and expansion from naïve $\mathrm{T}$ cells, but also highlight the optimal cytokine condition for differentiation and expansion of genetically engineered $\mathrm{T}_{\mathrm{SCM}}$ cells suitable for cancer adoptive cellular therapy.

Roberto et al. studied $\mathrm{T}_{\mathrm{SCM}}$ cell generation in preclinical models of hematopoietic stem cell transplantation (HSCT). $\mathrm{T}_{\mathrm{SCM}}$ cells arise from donor naïve $\mathrm{T}$ cells and are abundant early after haploidentical HSCT combined with posttransplant cyclophosphamide therapy. $\mathrm{T}_{\mathrm{SCM}}$ cells exhibit superior reconstitution capacity (11). Cieri et al. investigated $\mathrm{T}_{\mathrm{SCM}}$ cell generation in patients undergoing haploidentical HSCT. $\mathrm{T}_{\mathrm{SCM}}$ cells can differentiate directly from naïve precursors that are adoptively transferred with the graft. Similar to naïve T cells, $\mathrm{T}_{\text {SCM }}$ cells are able to generate the complete spectrum of $\mathrm{T}$ cell memory, including $\mathrm{T}_{\mathrm{SCM}}$ cells. By contrast, few $\mathrm{T}_{\mathrm{CM}}$ and $\mathrm{T}_{\mathrm{EM}}$ cells can convert into $\mathrm{T}_{\mathrm{SCM}}$ cells (12). Likewise, Oliveira et al. traced the thymidine kinase (TK) transduced $\mathrm{T}$ cells infused in patients after haploidentical HSCT. The phenotypic distribution of cytomegalovirus (CMV)- and Flu-specific $\mathrm{TK}^{+} \mathrm{T}$ cells in patients was investigated. Only when antigen-specific $\mathrm{T}_{\mathrm{SCM}}$ cells are detected in the infused cell population, a complete spectrum of antigen-specific $\mathrm{T}_{\mathrm{SCM}}, \mathrm{T}_{\mathrm{CM}}$, and $\mathrm{T}_{\mathrm{EM}}$ can be retrieved long-term in patients (13). These studies support a progressive model of memory $\mathrm{T}$ cell differentiation, following 
naive $\mathrm{T} \rightarrow \mathrm{T}_{\mathrm{SCM}} \rightarrow \mathrm{T}_{\mathrm{CM}} \rightarrow \mathrm{T}_{\mathrm{EM}}$. $\mathrm{TK}$ transduction of $\mathrm{T}$ cells prior to infusion has a unique advantage for tracing the infused $\mathrm{TK}^{+} \mathrm{T}$ cells overtime in patients after haploidentical HSCT. At a median followup of 6.8 years after cell infusion, low but stable levels of $\mathrm{TK}^{+} \mathrm{T}_{\mathrm{SCM}}$, $\mathrm{T}_{\mathrm{CM}}$, and $\mathrm{T}_{\mathrm{EM} / \mathrm{EFF}}$ cells are detected in all patients. Of note, the absolute counts of long-term persisting $\mathrm{TK}^{+}$cells are positively correlated with the amount of infused $\mathrm{T}_{\mathrm{SCM}}$ cells (13). This finding highlights that $\mathrm{T}_{\mathrm{SCM}}$ cells govern the quality and longevity of the adoptively transferred $\mathrm{T}$ cells. Consistent with this report, Biasco et al. analyzed $\mathrm{T}_{\mathrm{SCM}}$ cells in adenosine deaminase (ADA) deficient patients after infusion of ADA transduced mature lymphocytes or hematopoietic stem cells. Gene-transduced $\mathrm{T}_{\mathrm{SCM}}$ cells persist and preserve their precursor potential in patients for up to 12 years after infusion (14). Fuertes Marraco et al. tracked yellow fever (YF) specific $\mathrm{CD}^{+} \mathrm{T}$ cells in humans after YF vaccination. Frequencies of YF-specific $C D 8^{+} \mathrm{T}_{\mathrm{CM}}$ and $\mathrm{T}_{\mathrm{EM}}$ cells decrease with time, but naïvelike YF-specific $\mathrm{CD}^{+} \mathrm{T}_{\mathrm{SCM}}$ cells are stably maintained for more than 25 years (15). Taken together, these studies show the direct development of $\mathrm{T}_{\mathrm{SCM}}$ cells from naïve $\mathrm{T}$ cells and provide fundamental insights into the stemness capacities of $\mathrm{T}_{\mathrm{SCM}}$ cells. The self-renewal capacity leads to the long-term persistence of $\mathrm{T}_{\mathrm{SCM}}$ cells, whereas multipotency enables $\mathrm{T}_{\mathrm{SCM}}$ cells to differentiate into the complete spectrum of memory and effector cells. The stemness of $\mathrm{T}_{\mathrm{SCM}}$ cells should be taken into consideration when developing vaccines or immunotherapies.

Wnt- $\beta$-catenin, an evolutionarily conserved pathway, plays an essential role in regulating cell stemness. Gattinoni et al. discovered that Wnt signaling also promotes stemness in memory $\mathrm{T}$ cells (7). The Wnt pathway effector TCF1 has now been recognized as a central player of $\mathrm{T}$ cell stemness, which will be discussed throughout this review (16).

\section{T CELL EXHAUSTION DURING CHRONIC ANTIGEN EXPOSURE}

The seeming antithesis of "stemness" and self-renewal is "exhaustion". The broad term describes a T cell state first seen in chronic viral infection $(17,18)$. Almost three decades ago, Moskophidis et al. infected mice with the noncytopathic lymphocytic choriomeningitis virus (LCMV) strain Docile (D). The presence of large numbers of LCMV-D produced high antigen loads that forced exhaustion of the specific antiviral $\mathrm{CD}^{+}$cytotoxic $\mathrm{T}$ cells. Due to the technical limitation at that time, the authors indicated that their findings explained mechanistically, but not yet molecularly, the puzzle of why high-dose LCMV infection diminishes T cell responses $(18,19)$.

Nowadays, systems immunology approaches permit insight beyond the traditional cell surface-marker or cytokine expression, allowing us to peer at the transcriptional, epigenetic, and metabolic programming underpinning various T cell states. In 2007, Wherry et al. used microarray analysis to investigate the molecular signature of $\mathrm{CD}^{+} \mathrm{T}$ cell exhaustion after chronic LCMV infection. CD8 ${ }^{+} \mathrm{T}_{\mathrm{EX}}$ cells overexpressed PD-1 and other inhibitory receptors, expressed a distinct set of transcription factors, and had profound metabolic and bioenergetic deficiencies (20). These findings initiatively revealed how $\mathrm{T}_{\mathrm{EX}}$ cells progressively lose effector functions at the molecular level.

ScRNA-seq technique has opened a new dimension for studying $\mathrm{T}$ cell biology. Many of the initial scRNA-seq studies examined $\mathrm{T}$ cell states in different types of cancer. $\mathrm{CD}^{+} \mathrm{T}_{\mathrm{EX}}$ cells are often preferentially enriched in the tumor microenvironment $(21,22)$. Since then, $\mathrm{T}$ cell exhaustion has become an accepted term to describe the response of $\mathrm{T}$ cells to both chronic infection and cancer (23-29).

\section{STEMNESS OF $\mathrm{T}_{\mathrm{PEX}}$ CELLS}

PD-1-PD-L1 checkpoint blockade is effective for treatment of different cancers. Because $\mathrm{T}_{\mathrm{EX}}$ cells often express high levels of PD-1, reversal of $\mathrm{T}$ cell exhaustion was considered as a mechanism underlying PD-1-PD-L1 blockade. This view was dramatically changed in 2016 when $\mathrm{TCF} 1^{+} \mathrm{PD}-1^{+} \mathrm{T}_{\mathrm{PEX}}$ cells were discovered. Im et al. investigated how PD- 1 blockade regulates $\mathrm{CD}^{+} \mathrm{T}$ cell responses during chronic LCMV infection. They found that a $\mathrm{TCF} 1^{+} \mathrm{PD}-1^{+} \mathrm{CD} 8^{+} \mathrm{T}$-cell subset resembles stem cells during chronic LCMV infection, undergoing self-renewal and also differentiating into terminal TCF $1^{-} \mathrm{PD}-1^{+} \mathrm{T}_{\mathrm{EX}}$ cells. TCF1 is not only a marker for this cell subset, but also has an important role in their generation. More importantly, the proliferative burst after PD1 blockade comes almost exclusively from this cell subset (30). This cell subset has amassed many names, including "stem-like", "memory-like", "follicular cytotoxic", "exhausted progenitor", and "precursors of exhausted" $\mathrm{T}$ cells. Herein we prefer the term "precursors of exhausted" $\mathrm{T}\left(\mathrm{T}_{\mathrm{PEX}}\right)$ that better describes the relationship between $\mathrm{T}_{\mathrm{PEX}}$ and $\mathrm{T}_{\mathrm{EX}}$ cells (3).

Siddiqui et al. have investigated the stem-like properties of $\mathrm{TCF} 1^{+} \mathrm{PD}-1^{+}$tumor-infiltrating $\mathrm{CD}^{+} \mathrm{T}$ lymphocytes (TILs). TCF $1^{+} \mathrm{PD}-1^{+}$TILs exhibited stem-like functions as they mediated the proliferative response to immunotherapy, generating both TCF $1^{+} \mathrm{PD}-1^{+}$and differentiated $\mathrm{TCF} 1^{-} \mathrm{PD}-1^{+}$cells. A Tcf7diphtheria toxin receptor (DTR) system was creatively designed to deplete tumor-specific $\mathrm{TCF} 1^{+} \mathrm{CD} 8^{+} \mathrm{T}$ cells. Ablation of $\mathrm{TCF} 1^{+} \mathrm{PD}-1^{+}$TILs indeed restricted responses to immunotherapy. The authors concluded that immune checkpoint blockade relies on the proliferation of stem-like TCF $1^{+} \mathrm{PD}-1^{+} \mathrm{TILs}$, but not on reversal of $\mathrm{T}$ cell exhaustion programs (31).

In a viewpoint article, 18 experts in the $\mathrm{T}$ cell biology field described their thoughts on $\mathrm{T}$ cell exhaustion. They highlighted that terminally differentiated $\mathrm{TCF} 1^{-} \mathrm{T}_{\mathrm{EX}}$ cells are derived from the self-renewing $\mathrm{TCF}^{+}$precursor population, with stem celllike properties akin to memory T cell populations (29). The term "stemness" is now increasingly being used in the literature to refer to the stem cell-like properties of $\mathrm{T}_{\mathrm{PEX}}$ cells.

\section{TRANSCRIPTIONAL REGULATION OF T CELL STEMNESS}

Fearon et al. postulated twenty years ago that the stem cell-like capacity not only promotes $\mathrm{T}$ cell memory but also sustains 
chronic $\mathrm{T}$ cell response, and that some transcription factors may exist in $\mathrm{T}$ cells to maintain stem cell-like capacity and restrain terminal differentiation (32). Since then, transcription factors regulating $\mathrm{T}$ cell stemness have been gradually revealed. The transcription factor TCF1 has been identified as not only a marker, but also a key regulator of memory $\mathrm{T}$ cell stemness. During an acute infection, antigen-specific $\mathrm{CD} 8^{+} \mathrm{T}$ cells can be broadly divided into IL-7R $\alpha^{\text {low }}$ KLRG $1^{\text {hi }}$ terminal effectors and

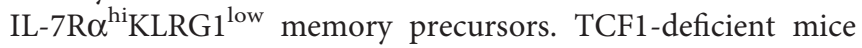
mount a normal primary effector $\mathrm{T}$ cell response, but they essentially lack $\mathrm{CD}^{+}$memory precursors at the peak of acute infection (33). After acute infection, TCF1 deficiency severely impairs $\mathrm{CD}^{+} \mathrm{T}_{\mathrm{CM}}$ differentiation, longevity, and response to recall antigens $(33,34)$. These findings demonstrate that TCF1 programs $\mathrm{CD}^{+}$memory $\mathrm{T}$ cell stemness and fate.

TCF1 is also both a marker and a key regulator for $\mathrm{T}_{\mathrm{PEX}}$ cells during chronic antigen exposure $(30,35)$. TCF1 deficiency abrogates $\mathrm{T}_{\mathrm{PEX}}$ cell generation, leading to an impairment of viral control $(30,35)$. Chen et al. used scRNA-seq and lineage tracing to study $\mathrm{T}$ cell states early during chronic infection. They found that TCF1 represses the development of KLRG ${ }^{\text {hi }}$ terminal effector $\mathrm{T}$ cells while fostering $\mathrm{T}_{\mathrm{PEX}}$ cells (36). Hence, although TCF1 promotes $\mathrm{T}_{\mathrm{PEX}}$ cell generation and sustains chronic response, it may restrain $\mathrm{T}$ cells to exert immediate effector function (36).

The transcription factor $\mathrm{BACH} 2$ is required for $\mathrm{CD}^{+} \mathrm{T}$ cell memory differentiation. Roychoudhuri et al. mapped genomewide $\mathrm{BACH} 2$ binding sites using ChIP-seq. They found that $\mathrm{BACH} 2$ binds to enhancers of TCR-driven genes, attenuating the availability of AP-1 sites to Jun family transcription factors. This process restrains terminal effector programs. Effector T cells thus downregulate $\mathrm{BACH} 2$ expression to promote effector fate differentiation. By contrast, $\mathrm{BACH} 2$ expression enables the generation of long-lived memory cells (37).

$\mathrm{BACH} 2$ is an essential regulator for $\mathrm{T}_{\mathrm{PEX}}$ cells during chronic antigen exposure. Utzschneider et al. and Yao et al. independently showed that $\mathrm{BACH} 2$ deficiency impairs the generation of $\mathrm{TCF}^{+}{ }^{+} \mathrm{CD}^{+} \mathrm{T}_{\mathrm{PEX}}$ cells, whereas $\mathrm{BACH} 2$ overexpression enforces their generation at the early phase of chronic infection $(38,39)$. By using single-cell transcriptomic and epigenomic approaches, Yao et al. further revealed that $\mathrm{BACH} 2$ itself is transcriptionally and epigenetically active in $\mathrm{T}_{\mathrm{PEX}}$ cells but not in $\mathrm{T}_{\mathrm{EX}}$ cells. Moreover, $\mathrm{BACH} 2$ establishes the transcriptional and epigenetic programs of stem-like $\mathrm{CD}^{+} \mathrm{T}_{\mathrm{PEX}}$ cells, while suppressing the molecular program that drives terminal exhaustion. Therefore, BACH2 actively enforces commitment to stem-like $\mathrm{CD}^{+} \mathrm{T}_{\mathrm{PEX}}$ lineage and guards $\mathrm{T}_{\mathrm{PEX}}$ cells against terminal exhaustion (39).

Id3, a member of the Id protein family which negatively regulates E-protein DNA-binding (40), is essential for $\mathrm{CD}^{+}$ memory $\mathrm{T}$ cell formation (41). In the above-mentioned study by Utzschneider et al., Id3 was highly expressed among $\mathrm{TCF}^{+}{ }^{+} \mathrm{TIM}^{-} \mathrm{T}_{\mathrm{PEX}}$ cells. Both Id 3 and TCF1 are progressively lost when $\mathrm{T}_{\mathrm{PEX}}$ cells terminally differentiate into $\mathrm{TIM}^{+} \mathrm{T}$ cells (38). Thus, both Id 3 and TCF1 are transcriptional markers of $\mathrm{T}_{\text {PEX }}$ cells. Whether Id3 regulates the $\mathrm{T}_{\mathrm{PEX}}$ cell state remains unexamined.
The transcription factor $\mathrm{c}-\mathrm{Myb}$ is another pivotal regulator of $\mathrm{CD}^{+} \mathrm{T}$ cell stemness. Following an antitumor vaccination, $M y b$-deficient $\mathrm{CD}^{+} \mathrm{T}$ cells are prone to terminal differentiation, generating fewer stem cell-like Tcm cells than do $M y b$-sufficient $\mathrm{T}$ cells. By contrast, $\mathrm{c}-\mathrm{Myb}$ overexpression promotes $\mathrm{CD}^{+} \mathrm{T}$ cell memory and recall responses that elicit therapeutic antitumor immunity. Mechanistically, c-Myb acts as a transcriptional activator of Tcf7 (encoding TCF1) to enhance stemness and as a repressor of Zeb2 to restrain effector differentiation (42). Systems immunology approaches have further shown that in $\mathrm{CD}^{+} \mathrm{T}$ cells, $\mathrm{c}-\mathrm{Myb}$ promotes formation of $\mathrm{T}_{\mathrm{SCM}}$ cells, restrains terminal differentiation, and fosters $\mathrm{TCF}^{+}{ }^{+} \mathrm{T}_{\mathrm{PEX}}$ cell persistence $(36,43)$.

Above discoveries suggest that memory cell formation and $\mathrm{T}_{\text {PEX }}$ cell generation are controlled by the same set of transcription factors, which maintains cell stemness and restrains terminal differentiation (Figure 1).

\section{TRANSCRIPTIONAL REGULATION OF EXHAUSTION}

T cell exhaustion occurs during chronic antigen stimulation. We and others showed that high antigen load drives $\mathrm{T}$ cell exhaustion. High antigen load not only maintains antigen chronicity but may also provide repeated antigen stimulation via TCR to initiate exhaustive differentiation during the early phase of a chronic response (44).

TCR-induced calcium-calcineurin signal activates the NFAT family of transcription factors. Activated NFAT proteins in turn interact with other transcription factors (e.g., AP-1 family) to govern $T$ cell activation and effector cell differentiation. Martinez et al. demonstrated that NFAT proteins also drive the transcriptional program of $\mathrm{CD}^{+} \mathrm{T}$ cell exhaustion. $\mathrm{CD}^{+} \mathrm{T}$ cells lacking NFAT fail to express exhaustion-related inhibitory receptors. The authors generated an engineered form of NFAT1 that cannot interact with AP-1 transcription factors. With this engineered NFAT, they showed that NFAT drives $\mathrm{T}$ cell exhaustion by binding at genomic regions sites that do not require cooperation with AP-1 (45).

Calcineurin inhibitor FK506, a mainstay immuno-suppressant, inhibits NFAT nuclear translocation and its transcriptional activity. Philip et al. showed that low-dose FK506 decreases the expression of inhibitory receptors PD1 and LAG-3 and increases TCF1 expression in $\mathrm{CD}^{+} \mathrm{T}$ cells during chronic exposure to a tumor antigen. Hence, partial downregulation of NFAT activity helps to prevent $\mathrm{T}$ cell exhaustion/dysfunction (46).

TOX is a secondary transcription factor induced by initiating NFAT. TOX likely does not participate in the differentiation of effector and memory $\mathrm{T}$ cell states in response to acute infection. On the contrary, in chronic infection and cancer, TOX is a key driver of the exhaustion program in $\mathrm{CD}^{+} \mathrm{T}$ cells. In year 2019, five papers from different groups reported that TOX expression is pivotal for the formation and maintenance of $\mathrm{TCF} 1^{+} \mathrm{T}_{\mathrm{PEX}}$ cells and the subsequent differentiation of terminal $\mathrm{T}_{\mathrm{EX}}$ cells (47-51). Without TOX, the $\mathrm{T}_{\mathrm{PEX}}$ cell formation is impaired, and $\mathrm{T}_{\mathrm{EX}}$ cells 


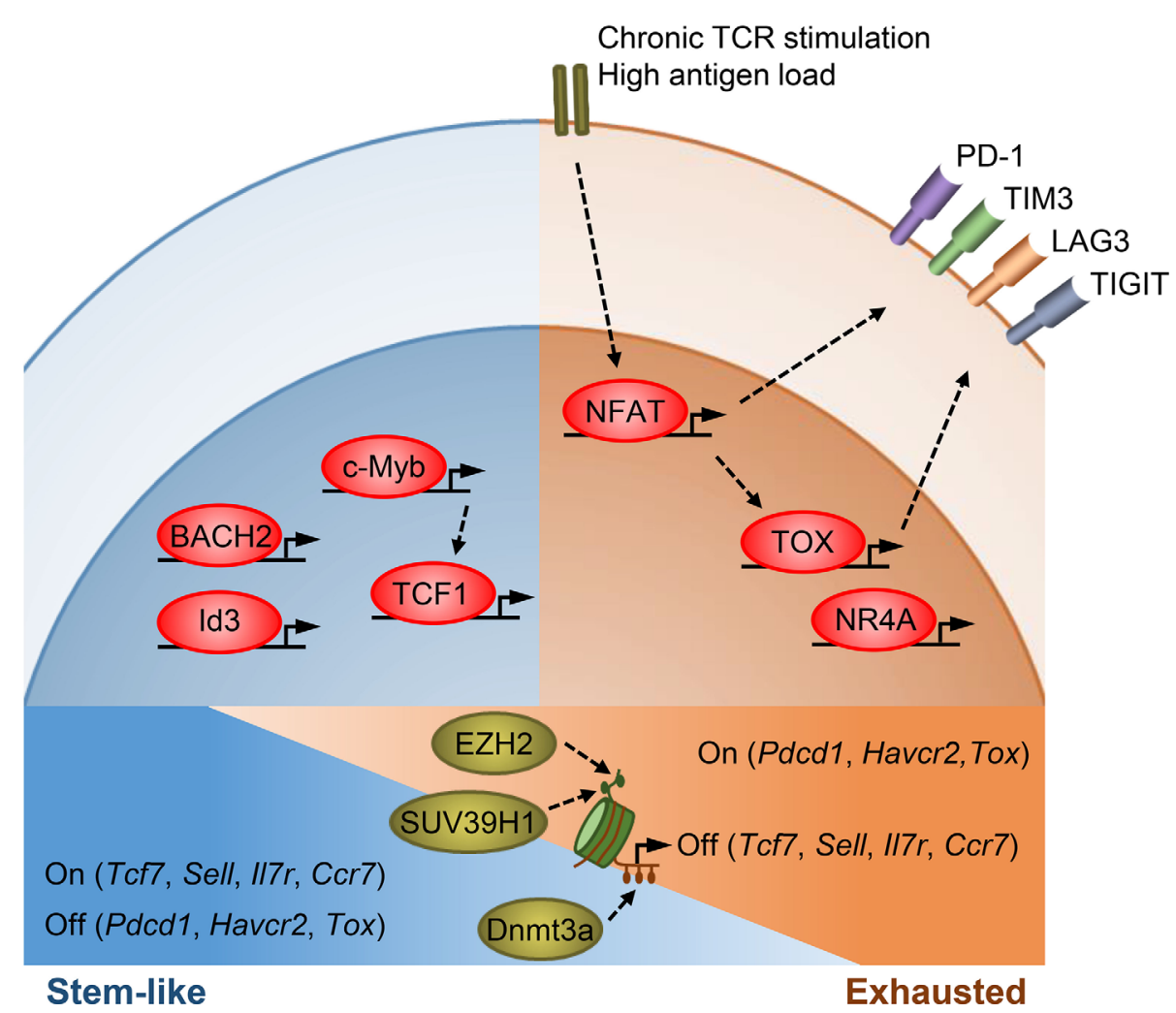

FIGURE 1 | Transcriptional and epigenetic regulation of T cell stemness and exhaustion. Transcription factors TCF1, BACH2, Id3, and c-Myb promote memory T cell formation as well as stemness in TPEX cells. TCF1, BACH2, and c-Myb also restrain effector T cell differentiation. c-Myb is a transcriptional activator of Tcf7. Under chronic antigen exposure or high antigen load, the TCR-NFAT-TOX/NR4A axis drives the exhaustion program of T cells and promotes the expression of multiple inhibitory receptors. TOX/TOX2 and NR4As are secondary transcription factors induced by initiating NFAT. Epigenetic mechanisms, such as histone modifications and DNA methylation, act in concert with transcription factors to regulate T cell states. SUV39H1 and EZH2 silence stem/memory genes during effector T cell differentiation by methylating $\mathrm{H} 3 \mathrm{~K} 9$ and $\mathrm{H} 3 \mathrm{~K} 27$, respectively. Dnmt3a mediates de novo DNA methylation to inhibit the expression of stem/memory genes during effector differentiation. $T_{E X}$ cells have an epigenetic profile distinct from that of $T_{E F F}$ and memory $T$ cells, though how epigenetic enzymes regulate the expression of exhaustion genes remains unclear.

do not form. Tox-deleted CD8 ${ }^{+}$cells did not upregulate genes for inhibitory receptors, such as $P d c d 1$, Entpd1, Havcr2, Cd244 and Tigit (48).

Although TOX drives the exhaustion program in $\mathrm{CD}^{+} \mathrm{T}$ cells, its deletion does not effectively potentiate chronic $\mathrm{T}$ cell response. Scott A et al. showed that Tox-deleted antitumor $\mathrm{CD} 8^{+}$ cells remain dysfunctional in tumors. The reduced expression of inhibitory receptors on them does not prevent the loss of effector function (48). Yao et al. evidenced that ectopic expression of TOX even endows terminal $\mathrm{CD}^{+} \mathrm{T}_{\mathrm{EX}}$ cells with the ability to persist during chronic viral infection (50). Alfei et al. showed that TOX-mutated $\mathrm{T}$ cells initially mediate increased effector function but eventually undergo a massive decline in their quantity. This is possibly due to the critical role of TOX in maintaining TCF $1^{+}$ self-renewing $\mathrm{T}_{\mathrm{PEX}}$ cells (49).

In a model of CNS autoimmunity, Page et al. showed that TOX is required for the persistence of self-reactive $\mathrm{CD} 8^{+} \mathrm{T}$ cells. The authors used systems immunology to characterize the transcriptional and epigenetic landscape of self-reactive $\mathrm{CD} 8^{+} \mathrm{T}$ cells. They found that continuous exposure to CNS self-antigen sustains TOX expression in self-reactive T cells, and that TOX remodels more than 400 genomic regions including the $T c f 7$ loci (52). Therefore, along with the line that TOX maintains $\mathrm{TCF}^{+}$ $\mathrm{T}_{\mathrm{PEX}}$ cells (49), TOX may modulate TCF1 expression. The above discoveries collectively suggest that $\mathrm{T}$ cells express TOX to adapt their response to persistent antigen stimulation, and that TOX affects chronic $\mathrm{T}$ cell responses in a multi-factorial, contextdependent manner.

NR4As (NR4A1, NR4A2, and NR4A3) are also secondary transcription factors induced by initiating NFAT. $\mathrm{CD} 8^{+} \mathrm{T}$ cells express high levels of NR4As upon chronic viral infections or in tumors. Chen et al. showed that NR4As have an important role in the program of $\mathrm{T}$ cell dysfunction/exhaustion. Knocking out all three NR4As in CAR T cells promotes tumor regression and prolongs the survival of tumor-bearing mice (53). Liu et al. demonstrated that NR4A1 is preferentially recruited to AP-1 binding sites and represses effector-gene expression by inhibiting AP-1 function. Deletion of NR4A1 overcomes T cell dysfunction, exaggerates effector function, and enhances immunity against tumor and chronic virus (54).

BATF is a member of the AP- 1 family transcription factors. It dimerizes with JunB and acts as a repressor of AP-1 activities in 
activated T cells. Quigley et al. suggested that BATF is one of the exhaustion drivers. Elevated BATF expression correlates with $\mathrm{CD}^{+} \mathrm{T}$ cell exhaustion in response to HIV infection. Silencing BATF in T cells rescues HIV-specific T cell function (55). BATF, $\mathrm{BACH} 2$, and NR4A1 all have repressive roles for AP-1 activities. BACH2 suppresses AP-1-dependent effector genes to sustain $\mathrm{T}_{\text {PEX }}$ cells, whereas BATF and NR4A1 promote terminal exhaustion. Conversely, overexpression of the canonical AP-1 factor c-Jun has been shown to induce exhaustion resistance of antitumor CAR-T cells (56).

Taken together, the TCR-NFAT-TOX/NR4A axis drives the exhaustion program of $\mathrm{CD}^{+} \mathrm{T}$ cells (Figure 1). Further studies are required to define how $\mathrm{T}_{\mathrm{PEX}}$ cells repress their effector program to maintain stemness and how $\mathrm{T}_{\mathrm{EX}}$ cells forfeit their stemness and effector function.

\section{EPIGENETIC REGULATION OF STEMNESS DURING MEMORY T CELL DEVELOPMENT}

Upon acute infection, $\mathrm{T}$ cells undergo significant epigenetic reprograming to fulfill a variety of functions. Epigenetic mechanisms (e.g., DNA methylation and histone modifications), acting in concert with transcription factors, orchestrate $\mathrm{CD}^{+} \mathrm{T}$ cell differentiation and memory. This has been excellently reviewed elsewhere recently $(57,58)$. Here we focus on the epigenetic regulation of stemness in $\mathrm{T}$ cells.

The ontogeny of memory $\mathrm{T}$ cells after acute infection has been gradually revealed. Early after an acute infection, antigen-specific $\mathrm{CD}^{+} \mathrm{T}$ cells can branch into less-differentiated IL$7 \mathrm{R} \alpha^{\text {hi }} \mathrm{KLRG} 1^{\text {low }}$ memory precursors and more-differentiated IL-7R $\alpha^{\text {low }} K L R G 1^{\text {hi }}$ terminal effectors. This paradigm highlights that fully differentiated terminal effectors lose memory potential. Herndler-Brandstetter et al. have recently identified an IL$7 \mathrm{R}^{+} \mathrm{KLRG}^{+}$cell population that retains memory potential. IL-7R $\alpha^{+} \mathrm{KLRG}^{+}$cells represent effector $\mathrm{T}$ cells that are less differentiated than the IL-7R $\alpha^{-} \mathrm{KLRG}^{+}$terminal effectors. These cells receive intermediate amounts of activating signals, downregulate KLRG1 during the contraction phase, and can differentiate into all memory $\mathrm{T}$ cell linages (59). Hence, both IL$7 \mathrm{R} \alpha^{\text {hi }} \mathrm{KLRG}^{\text {low }}$ memory precursors and IL-7R $\alpha^{+} \mathrm{KLRG1}^{+}$ effector $\mathrm{T}$ cells have memory potential.

Investigation into epigenetic changes provides a better understanding of memory $\mathrm{T}$ cell development and stemness. DNA methylation generally inhibits gene expression in cells. Youngblood et al. investigated the Dnmt3a-dependent de novo DNA methylation in $\mathrm{CD}^{+} \mathrm{T}$ cells during acute infection. They found that $\mathrm{CD}^{+}$memory precursors initially acquire de novo DNA methylation programs to inhibit the expression of some naïve-associated genes and become demethylated at the loci of effector-associated genes (permitting expression). To develop into long-lived memory $\mathrm{T}$ cells, those memory precursors erase de novo methylation programs at naïve-associated gene loci to permit their re-expression, while key effector genes remain demethylated. Thus, $\mathrm{T}$ cells may lose and re-express some stemness/naïve-associated genes during memory cell development. Fully developed memory $\mathrm{T}$ cells express naïveassociated genes and are also poised to exert effector function upon re-infection (60).

Methylation of histone 3 lysines 9 (H3K9) and 27 (H3K27) is highly correlated with transcriptional repression. SUV39H1 is a histone methyltransferase that methylates H3K9. Pace et al. studied the role of SUV39H1 in regulating $\mathrm{CD}^{+} \mathrm{T}$ cell response upon infection. They showed that SUV39H1dependent trimethylation of $\mathrm{H} 3 \mathrm{~K} 9$ ( $\mathrm{H} 3 \mathrm{~K} 9 \mathrm{me} 3$ ) controls the expression of a set of stem-related memory genes. Suv39h1deificent $\mathrm{CD}^{+} \mathrm{T}$ cells fail to silence stem/memory genes during terminal effector cell differentiation and have increased longterm memory reprogramming capacity (61). Polycomb repressive complex 2 (PRC2) silences gene expression through methylation of H3K27. EZH2 is the catalytic subunit of PRC2. Gary et al. profiled $\mathrm{H} 3 \mathrm{~K} 27 \mathrm{me} 3$ in $\mathrm{CD}^{+} \mathrm{T}$ cells during viral infection. H3K27me3 deposition at numerous stem/memory genes during effector differentiation. Ezh2-deficiency impaired terminal effector cell differentiation (62). Therefore, H3K9me3 and $\mathrm{H} 3 \mathrm{~K} 27 \mathrm{me} 3$ deposition at stem/memory genes drive effector $\mathrm{T}$ cells to lose stemness and memory potential.

Developed memory cell subsets display distinct epigenetic landscapes. Durek et al. investigated the genome-wide profiles of DNA methylation in naive, $\mathrm{T}_{\mathrm{CM}}, \mathrm{T}_{\mathrm{EM}}$, and terminally differentiated memory $\mathrm{T}\left(\mathrm{T}_{\text {EMRA }}\right)$ cells. They observed a progressive global loss of DNA methylation in the order naïve$\mathrm{T}_{\mathrm{CM}}-\mathrm{T}_{\mathrm{EM}}-\mathrm{T}_{\mathrm{EMRA}}$. Mean DNA methylation levels for the entire genome drop from $84 \%$ in naïve $\mathrm{T}$ cells to $67 \%$ in $\mathrm{T}_{\mathrm{EMRA}}$ cells. This study highlights that developed memory $\mathrm{T}$ cells contain subsets with different differentiation states (63).

We interpret the above findings by suggesting that regardless of the types and phases of a $\mathrm{T}$ cell response, each state always includes less- or more-differentiated T cells. Stem/naïve/memory genes are expressed in less-differentiated $\mathrm{T}$ cells to ensure $\mathrm{T}$ cell persistence and are epigenetically silenced in terminal effector $\mathrm{T}$ cells to fulfill effector function (Figure 1).

\section{EPIGENETIC HALLMARKS OF T CELL EXHAUSTION}

The epigenetic profile of exhausted T cells differs markedly from those of effector and memory T cells. Sen et al. used ATAC-seq to define chromatin-accessible regions (ChARs) in $\mathrm{CD}^{+} \mathrm{T}$ cells. Upon both acute and chronic infections, antigen stimulation of naïve T cells leads to dramatic remodeling of ChARs. About $71 \%$ ChARs either emerged or disappeared when naïve $\mathrm{T}$ cells undergo differentiation. The authors then compared the ChARs of $\mathrm{T}_{\mathrm{EX}}$ cells post-chronic infection with those of effector/memory $\mathrm{T}$ cells post-acute infection. $\mathrm{T}_{\mathrm{EX}}$ cells exhibit higher peak intensity of ChARs adjacent to exhaustionassociated genes (e.g., Pdcd1, Havcr2, Batf) than do effector/ memory T cells. After examining the ChARs adjacent to $P d c d 1$, the authors indeed identified a new enhancer that promotes PD-1 expression in exhausted T cells (64). 
Pauken et al. demonstrated the high stability of exhaustionassociated ChARs in $\mathrm{CD}^{+} \mathrm{T}_{\mathrm{EX}}$ cells using an infection model. After establishing chronic infection and $\mathrm{T}$ cell exhaustion with LCMV-Cl13, Paueken et al. reinvigorated $\mathrm{T}$ cell response and cleared LCMV-Cl13 infection with PD-L1 blockade. Interestingly, after PD-L1 blockade and LCMV-Cl13 clearance, reinvigorated $\mathrm{T}$ cells fail to become functional memory $\mathrm{T}$ cells. The authors found that upon LCMV-Cl13 infection, antigenspecific $\mathrm{T}$ cells acquire an exhaustion-associated epigenetic profile distinct from those of effector and memory $\mathrm{T}$ cells. Although PD-L1 blockade reinvigorates $\mathrm{T}$ cell response against LCMV-Cl13, it largely fails to remodel the exhaustion-associated epigenetic profile. The authors conclude that epigenetic stability of $\mathrm{T}_{\mathrm{EX}}$ cells limits durability of PD-L1-blockade effects (65).

Weber et al. showed that epigenetic remodeling occurs in exhausted chimeric antigen receptor (CAR)- $\mathrm{T}$ cells after transient rest. Rest is induced in CAR-T cells by using a drugregulatable degron system. Rest for as few as four days induces global epigenetic remodeling in exhausted CAR-T cells. The remodeled epigenetic profile resembles that of the nonexhausted control CAR-T cells. Importantly, transient rest restores antitumor functionality in exhausted CAR-T cells (66). Taken together, $\mathrm{T}_{\mathrm{EX}}$ cells acquire an epigenetic profile distinct from those of effector and memory $\mathrm{T}$ cells (Figure 1). The stability of exhaustion-associated epigenetic state may be different in exhausted CAR-T cells than in $\mathrm{T}_{\mathrm{EX}}$ cells.

\section{IMPACT OF THE TISSUE ENVIRONMENT AND METABOLISM}

Anatomical location and proximity to antigen inform $\mathrm{T}$ cell states. This was noted early in chronic viral infection studies, where the more terminally differentiated $\mathrm{T}_{\mathrm{EX}}$ cells resided in the red pulp of the spleen, the major site of LCMV infection (30). The less-differentiated $\mathrm{T}_{\mathrm{PEX}}$ cells (retaining CXCR5 and TCF1) primarily localized to the T-cell zones of the white pulp (30). A recent study of type 1 diabetes showed that self-reactive $\mathrm{CD} 8^{+} \mathrm{T}$ cells in lymphoid tissue are less differentiated, retaining a hybrid of stem/naive and effector epigenetic programs. After infiltrating into pancreas, the site of the antigen, self-reactive $\mathrm{CD} 8^{+} \mathrm{T}$ cells exhibit mainly effector epigenetic programs and lose the stem/ naive-like state (67).

Is the environment instructing $\mathrm{T}$ cell states, via ligand binding (30), nutrient availability (68-71), and local cytokine production (44)? Is antigen abundance $(44,72-74)$ due to proximity $(30,67)$ causing excess TCR stimulation (75), to push into terminal effector differentiation or exhaustion? The answers to these questions are far from clear and simple. As one example, CXCR5 is the major B cell zone chemokine receptor. How are CXCR5 ${ }^{+} \mathrm{CD} 8^{+} \mathrm{T}_{\mathrm{PEX}}$ cells retained in the $\mathrm{T}$ cell zones (30)? $\mathrm{CXCR}^{+} \mathrm{CD}^{+} \mathrm{T}_{\mathrm{PEX}}$ cells have high expression levels of $\mathrm{Xcl1}$, which encodes a chemokine and promotes XCR $1^{+}$lymphoid dendritic cell interactions (30), present mainly in white pulp. This and other features of $\mathrm{T}_{\mathrm{PEX}}$ cells (expressing CCR7 and CD69) may contribute to their retention in the $\mathrm{T}$ cell zones (76).
Defining the tissue-specific triggers of various $\mathrm{T}$ cell states will unlock our understanding of the pathogenicity of many immune-mediated conditions. As an example, environmental factors have long been presumed to play an essential role in triggering autoimmune diseases. For instance, high salt diet can trigger enhanced $\mathrm{T}$ follicular helper cells ( $\mathrm{Tfh}$ ) in systemic lupus erythematosus (SLE), a T cell compartment implicated in SLE pathogenesis, by inducing DNA methylation per recruitment of the hydroxytransferase Ten-Eleven Translocation 2 (TET2) (69). High $\mathrm{NaCl}$ also activates the p38/MAPK pathway in experimental autoimmune encephalomyelitis (EAE), enhancing another pathogenic T cell compartment, Th17 (70). Another study examined metabolic impacts on $\mathrm{T}$ cell function in leukemia treatment. Uhl et al. found that leukemic-cell-generated lactic acid impairs $\mathrm{T}$ cell glycolysis and proliferation. Mechanistically, lactic acid decreases the expression of glycolysis-related enzymes in $\mathrm{T}$ cells by lowering intracellular $\mathrm{pH}$. Sodium bicarbonate $(\mathrm{NaBi})$ treatment reverses the lactic acid-induced low intracellular $\mathrm{pH}$ and enhances graft-versus-leukemia activity of $\mathrm{T}$ cells (77). The tissue environment may represent an attractive target for improving or dampening $\mathrm{T}$ cell function. Likewise, Zhang et al. found that high glucose intake worsens EAE and colitis, upregulating mitochondrial ROS to mediate increased TGF- $\beta$ production, thus promoting Th17 cell differentiation. Interestingly, $\mathrm{T}$ cell metabolism remained unchanged despite high glucose intake (78). Further studies examining metabolic drivers of $\mathrm{T}$ cell states are warranted.

How the local tissue microenvironment influences autoimmunity remains largely unknown. As mentioned above, self-reactive $\mathrm{T}$ cells are less differentiated in periphery and more terminally differentiated at target tissue sites (67). Chen et al. recently investigated the states of renal infiltrating $\mathrm{T}$ cells in lupus nephritis. Renal infiltrating T cells express PD-1 but most are $\mathrm{PD}-1^{\text {low }}$. Heightened renal hypoxia in lupus nephritis drives $\mathrm{CD}^{+}$and $\mathrm{CD}^{+}$infiltrating $\mathrm{T}$ cells to express hypoxia-inducible factor 1 (HIF-1), activating a HIF-1-PDK2-bnip3 hypoxia survival axis. HIF-1 also overrides c-Myc, sponsoring glycolysis via $\mathrm{NAD}^{+}$-regenerating proline metabolism. HIF-1 blockade inhibits infiltrating $\mathrm{T}$ cells and reverses tissue hypoxia and renal injury. The authors thus suggest that chronic antigen stimulation in the kidney does drive the upregulation of PD-1 and exhaustion program in the PD- ${ }^{\text {hi }}$ infiltrating $\mathrm{T}$ cells, yet despite this, many $\mathrm{T}$ cells retain pathogenic effector functions while still remaining PD-1 ${ }^{\text {lo }}$ (79). Hypoxia-driven HIF circuits maintain $\mathrm{T}$ cell function in targeted tissues, even with chronic antigen stimulation and inhibitory receptors $(79,80)$.

As another example, in the tumor microenvironment, elevated extracellular potassium from cancer cell necrosis inhibits TCR-driven Akt-mTOR phosphorylation and TIL effector function. This inhibition is dependent on the activity of the serine/threonine phosphatase PP2A (81). Moreover, high levels of extracellular potassium modify the epigenetic program by a nutrient-deprived state (82). When nutrient uptake is impaired, nucleocytosolic acetyl-coenzyme A and methionine intermediate deficiencies lead to reduced histone acetylation of the effector program and maintenance of stemness (82). 
Other local immune cells modify the tumor microenvironment and thus the $\mathrm{T}$ cell response. Intriguingly, tumor-associated macrophages can secrete endogenous glucocorticoids, which downregulate effector function and contribute to $\mathrm{T}$ cell dysfunction and poor checkpoint blockade response (68). M2like suppressive macrophages within the tumor microenvironment form bidirectional inhibitory interactions with exhausted EOMES $^{\text {hi }} \mathrm{CD}^{+} \mathrm{T}$ cells, predicting worse outcomes (83).

Understanding the impact of tissue environment on $\mathrm{T}$ cell function, metabolism, and state-switching will enlighten our paradigms of transplant, infection, autoimmunity, and cancer.

\section{A STEPWISE MODEL OF ACQUIRING T CELL EXHAUSTION WHILE LOSING STEMNESS}

Systems immunology approaches excel in revealing $\mathrm{T}$ cell states. Azizi et al. analyzed scRNA and TCR sequencing data from breast cancer. They showed that most $\mathrm{T}$ cells advance on continuous differentiation trajectories (84). Li et al. analyzed scRNA-seq data from melanoma. They indicate early effector $\mathrm{CD}^{+}$TILs transition into dysfunctional $\mathrm{T}$ cells in continuous progression (85). Based on the trajectory and TCR analysis of TILs in liver cancer, Zheng et al. showed that GZMK and GZMA expressing TILs represent an intermediate phase prior to terminal differentiation into $\mathrm{T}_{\mathrm{EX}}$ cells (21).

Recently, Galletti et al. discovered two distinct stem/memorylike $\mathrm{T}$ cells differentiated by Granzyme $\mathrm{K}$ (GZMK) expression (86). The T cells retaining GZMK expressed an exhausted-like phenotype $\left(\mathrm{T}_{\mathrm{PEX}}\right)$ characterized by $\mathrm{PD}-1$ and TIGIT inhibitory receptors, along with a transcriptional exhaustion signature (TOX, NFATC2, BATF, and others). In contrast, the T cells lacking GZMK showed a stem-like phenotype $\left(\mathrm{T}_{\mathrm{SCM}}\right)$, with expanded proliferative and cytokine-producing capacity. Interestingly, the $\mathrm{GZMK}^{+} \mathrm{T}_{\mathrm{PEX}}$ cells generated cytokines most effectively in a TCR-independent manner. The $\mathrm{T}$ cell receptor repertoire did not overlap between $\mathrm{GZMK}^{+}$or $\mathrm{GZMK}^{-}$ populations, suggesting independence and potentially unique antigen-induction (86). Also, these T cell compartments appear among the normal human memory $\mathrm{T}$ cell population $(86,87)$, whereas most prior studies have focused on their existence in pathological states.

Beltra et al. described a stepwise model of progressive exhaustion, with four distinct transition states, differentiated with Ly108/TCF1 and CD69 (88). Two exhaustion progenitor states displayed similar chromatin signatures while maintaining distinct transcriptional and functional identities. $\mathrm{T}_{\mathrm{Ex}}$ progenitor one, quiescent and resident, transition to $\mathrm{T}_{\mathrm{EX}}$ progenitor two, triggered by location change (from tissue to circulationaccessible) and proliferation. Next, a $\mathrm{T}_{\mathrm{EX}}$ intermediate could arise, eventually becoming terminally differentiated ( $T_{\mathrm{EX}}$ terminal). Transcription factors are dynamically expressed throughout the transition stages until reaching terminal differentiation, characterized by low levels of TCF1 and T-bet and high upregulation of TOX and Eomes. T-bet provoked the loss of TCF1. Future work could address if this loop feeds forward (88). TOX apparently antagonized T-bet, ultimately maintaining the upper hand as T-bet expression falls in $\mathrm{T}_{\mathrm{EX}}$ terminal cells (88). T-bet also repressed PD-1 in $\mathrm{T}_{\mathrm{EX}}$ cells, and PD-1 expression slowly faded as the $\mathrm{T}_{\mathrm{EX}}$ cells progress to terminal differentiation (89). PD-1 may protect $\mathrm{T}_{\mathrm{EX}}$ progenitors, through attenuation of TCR signaling $(30,36,88)$.

Taken together, the understanding of $\mathrm{T}$ cell states during chronic antigen exposure has exploded in the past years. From the $\mathrm{TCF}^{+}{ }^{+} \mathrm{T}_{\mathrm{PEX}}$-to-TCF1 ${ }^{-} \mathrm{T}_{\mathrm{EX}}$ transition model of exhaustion, a more sophisticated, stepwise model of $\mathrm{T}$ cell state-switching has evolved.

\section{PERSPECTIVES ON T CELL STEMNESS AND EXHAUSTION IN ORGAN TRANSPLANTATION}

Solid organ transplantation is a lifesaving treatment for patients with end-stage organ failure. Allogeneic $\mathrm{T}$ cell response plays a decisive role in rejecting the transplanted organs. Most transplant patients must take immunosuppressive drugs daily to inhibit allogeneic $\mathrm{T}$ cell response as long as the transplanted organs remain functional. Yet, immune rejection and immunosuppressive drug side effects still limit long-term allograft survival (90).

A question lingers: why does daily immunosuppression often fail to eliminate allogenic T cell response completely? Do TCF $1^{+}$ stem-like $\mathrm{T}$ cells enable the persistence of allogeneic $\mathrm{T}$ cell response? Lipson et al. reported a case in which an anti-PD-1 antibody was used to treat metastatic cancer in a kidney transplant patient. Though the anti-PD-1 treatment invigorated antitumor response, it induced transplant rejection (91). Later, Murakami et al. reported that among 69 kidney transplant patients who received immune checkpoint blockades to treat malignancies, 29 of whom developed acute rejection and 19 of whom lost their kidney allografts (92). It remains unknown whether immune checkpoint blockades invigorate $\mathrm{TCF} 1^{+}$stemlike allogenic $\mathrm{T}$ cells in key transplant patients.

Although few data have been reported to date, higher levels of circulating $\mathrm{T}_{\mathrm{EX}}$ cells have been shown to be associated with improved transplant outcome. Levitsky et al. observed increases in $\mathrm{T}_{\mathrm{EX}}$ cell populations in patients with tolerant liver transplants (93). Fribourg et al. identified both $\mathrm{CD} 4^{+}$and $\mathrm{CD} 8^{+}$circulating $\mathrm{T}_{\mathrm{EX}}$ cells in kidney transplant patients. Increase of $\mathrm{T}_{\mathrm{EX}}$ cell frequency after lymphocyte-depleting induction therapy correlates with improved transplant function (94).

We have previously found that deletion of a transcription factor IRF4 in $\mathrm{T}$ cells leads to transplant tolerance. Mechanistically, allogeneic Irf4-deficient $\mathrm{CD}^{+} \mathrm{T}$ cells progressively develop into an exhaustion-like phenotype, evident by their high PD-1 expression and impaired cytokine production (95). Miller et al. used CD154 blockade plus donorspecific transfusion to induce transplant tolerance. This tolerogenic protocol also induces a $\mathrm{PD}-1^{\text {hi }}$ phenotype of 
alloreactive T cells (96). Both IRF4 deletion and CD154 blockade eliminate $\mathrm{T}$ cell effector function. The $\mathrm{T}$ cell state under those tolerogenic conditions was thus named "T cell dysfunction" rather than exhaustion.

To investigate whether $\mathrm{T}$ cell exhaustion naturally occurs in transplantation without immunosuppression or gene deletion in $\mathrm{T}$ cells, we transplanted female $\mathrm{B} 6$ recipients with either largesize whole-tail skins or small-size tail skins from male B6 donors. Large- but not small-size male skins induce exhaustion of antimale $\mathrm{CD}^{+}$cells and are subsequently accepted by female recipients. In another model, we studied the natural exhaustion of allogenic $\mathrm{CD}^{+} \mathrm{T}$ cells. We used TCR-transgenic B6 TEa $\mathrm{CD}^{+}$cells that recognize Balb/c I-E $\alpha$ antigen. TEa CD $4^{+}$cells were adoptively transferred either into $\mathrm{B} 6$ recipients that received $\mathrm{Balb} / \mathrm{c}$ skins or into $\mathrm{F} 1$ offspring of $\mathrm{B} 6$ and Balb/c mice $(\mathrm{CB} 6 \mathrm{~F} 1)$ that contain abundant I-E $\alpha$ antigen. TEa cells in B6 recipient mice responded to $\mathrm{Balb} / \mathrm{c}$ skin transplantation and were not exhausted. By contrast, almost all TEa cells were quickly exhausted after adoptively transferring into CB6F1 mice. TEa cells in CB6F1 mice expressed high levels of NFATc1, TOX, NR4A1, and NR4A2. Thus, the abundant I-E $\alpha$ antigen in CB6F1 mice may drive the TCR-NFAT-TOX/NR4A exhaustion program in TEa cells (44).

Results from our exhaustion models conclude that high antigen load induces allogeneic $\mathrm{T}$ cell exhaustion. This may help explain why large liver allografts achieve tolerance more often than other organ allografts (93). This may also clarify why lymphocyte-depleting induction therapy induces allogeneic $\mathrm{T}$ cell exhaustion, as it dramatically increases the antigen-to- $T$ cell ratio (94). Currently, transplant recipients require lifelong use of FK506 or other immunosuppressive drugs. Although FK506 very effectively inhibits $\mathrm{T}$ cell effector programs, it also prevents $\mathrm{T}$ cell exhaustion by inhibiting the NFAT-TOX/NR4A axis $(45,47,53$, 97). For effective induction of transplant tolerance, it is essential to identify therapeutic approaches that not only inhibit the effector programs, but also promote allogeneic $\mathrm{T}$ cell exhaustion. Moreover, the role of $\mathrm{T}$ cell stemness in transplantation remains largely unknown and needs to be explored.

\section{CONCLUSIONS}

Nuanced T cell state dysregulation underpins the induction and maintenance of many disease states, notably organ transplant rejection, autoimmunity, chronic infection, and cancer. The past

\section{REFERENCES}

1. Goronzy JJ, Weyand CM. Successful and Maladaptive T Cell Aging. Immunity (2017) 46(3):364-78. doi: 10.1016/j.immuni.2017.03.010

2. Graef P, Buchholz VR, Stemberger C, Flossdorf M, Henkel L, Schiemann M, et al. Serial Transfer of Single-Cell-Derived Immunocompetence Reveals Stemness of CD8(+) Central Memory T Cells. Immunity (2014) 41(1):11626. doi: 10.1016/j.immuni.2014.05.018

3. Kallies A, Zehn D, Utzschneider DT. Precursor Exhausted T Cells: Key to Successful Immunotherapy? Nat Rev Immunol (2020) 20(2):128-36. doi: 10.1038/s41577-019-0223-7 few decades have yielded tremendous advances in our understanding of transcriptional, epigenetic, and metabolic regulations of $\mathrm{T}$ cell stemness and exhaustion. Reinvigoration of $\mathrm{T}$ cells in the tumor microenvironment with checkpoint blockade, for example, demonstrates the therapeutic power gained from understanding $\mathrm{T}$ cell states. $\mathrm{T}_{\mathrm{PEX}}$ exhaustion precursors can self-renew, give rise to terminally differentiated $\mathrm{T}_{\mathrm{EX}}$ cells, and respond to checkpoint blockade with a proliferative burst. C-Myb, Wnt, and TOX orchestrate TCF1 expression and thereby influence exhaustion or effector fate. Similarly, BACH2 inhibits AP-1 to sustain $\mathrm{T}_{\mathrm{PEX}}$ cells, while BATF and NR4A1 inhibit AP-1 to drive terminal exhaustion. $\mathrm{T}_{\text {PEX }}$ cells and $\mathrm{T}_{\mathrm{EX}}$ cells have distinct epigenetic signatures, impacted by resting states and hypoxia, to name a few. Antigen load also drives the exhaustion program, potentially via the TCR-NFAT-TOX/NR4A axis.

These exciting new discoveries of various $\mathrm{T}$ cell states and their regulators may give us the insight to target or exploit transition points. Currently, the mainstay of immunosuppressive therapies primarily target effector cells, while the quiescent $\mathrm{T}_{\mathrm{PEX}}$ cells can persist unperturbed, maintaining disease. Finding ways to modulate $\mathrm{T}_{\mathrm{PEX}}$ and $\mathrm{T}_{\mathrm{EX}}$ cell fate and function could revolutionize treatment in transplant rejection and autoimmunity.

As more mechanistic subtleties are brought to light, we can eventually learn to not merely harness the destructive power of the immune system, but also to tame it.

\section{AUTHOR CONTRIBUTIONS}

All authors listed have made a substantial, direct, and intellectual contribution to the work, and approved it for publication.

\section{FUNDING}

This study was supported by the US National Institutes of Health grant (\#NIH R01AI132492 to WC).

\section{SUPPLEMENTARY MATERIAL}

The Supplementary Material for this article can be found online at: https://www.frontiersin.org/articles/10.3389/fimmu.2021.725618/ full\#supplementary-material

4. Farber DL, Yudanin NA, Restifo NP. Human Memory T Cells: Generation, Compartmentalization and Homeostasis. Nat Rev Immunol (2014) 14(1):2435. doi: $10.1038 /$ nri3567

5. Chang JT, Wherry EJ, Goldrath AW. Molecular Regulation of Effector and Memory T Cell Differentiation. Nat Immunol (2014) 15(12):1104-15. doi: 10.1038/ni.3031

6. Gattinoni L, Lugli E, Ji Y, Pos Z, Paulos CM, Quigley MF, et al. A Human Memory T Cell Subset With Stem Cell-Like Properties. Nat Med (2011) 17 (10):1290-7. doi: 10.1038/nm.2446

7. Gattinoni L, Zhong XS, Palmer DC, Ji Y, Hinrichs CS, Yu Z, et al. Wnt Signaling Arrests Effector T Cell Differentiation and Generates CD8 
+ Memory Stem Cells. Nat Med (2009) 15(7):808-13. doi: 10.1038/ nm. 1982

8. Gattinoni L, Klebanoff CA, Restifo NP. Paths to Stemness: Building the Ultimate Antitumour T Cell. Nat Rev Cancer (2012) 12(10):671-84. doi: $10.1038 / \mathrm{nrc} 3322$

9. Zhang Y, Joe G, Hexner E, Zhu J, Emerson SG. Host-Reactive CD8+ Memory Stem Cells in Graft-Versus-Host Disease. Nat Med (2005) 11(12):1299-305. doi: $10.1038 / \mathrm{nm} 1326$

10. Cieri N, Camisa B, Cocchiarella F, Forcato M, Oliveira G, Provasi E, et al. IL-7 and IL-15 Instruct the Generation of Human Memory Stem T Cells From Naive Precursors. Blood (2013) 121(4):573-84. doi: 10.1182/blood-2012-05431718

11. Roberto A, Castagna L, Zanon V, Bramanti S, Crocchiolo R, McLaren JE, et al. Role of Naive-Derived T Memory Stem Cells in T-Cell Reconstitution Following Allogeneic Transplantation. Blood (2015) 125(18):2855-64. doi: 10.1182/blood-2014-11-608406

12. Cieri N, Oliveira G, Greco R, Forcato M, Taccioli C, Cianciotti B, et al. Generation of Human Memory Stem T Cells After Haploidentical T-Replete Hematopoietic Stem Cell Transplantation. Blood (2015) 125(18):2865-74. doi: 10.1182/blood-2014-11-608539

13. Oliveira G, Ruggiero E, Stanghellini MT, Cieri N, D’Agostino M, Fronza R, et al. Tracking Genetically Engineered Lymphocytes Long-Term Reveals the Dynamics of T Cell Immunological Memory. Sci Transl Med (2015) 7 (317):317ra198. doi: 10.1126/scitranslmed.aac8265

14. Biasco L, Scala S, Basso Ricci L, Dionisio F, Baricordi C, Calabria A, et al. In Vivo Tracking of T Cells in Humans Unveils Decade-Long Survival and Activity of Genetically Modified T Memory Stem Cells. Sci Transl Med (2015) 7(273):273ra13. doi: 10.1126/scitranslmed.3010314

15. Fuertes Marraco SA, Soneson C, Cagnon L, Gannon PO, Allard M, Abed Maillard S, et al. Long-Lasting Stem Cell-Like Memory CD8+ T Cells With a Naive-Like Profile Upon Yellow Fever Vaccination. Sci Transl Med (2015) 7 (282):282ra48. doi: 10.1126/scitranslmed.aaa3700

16. Kaech SM, Cui W. Transcriptional Control of Effector and Memory CD8+ T Cell Differentiation. Nat Rev Immunol (2012) 12(11):749-61. doi: 10.1038/nri3307

17. Zajac AJ, Blattman JN, Murali-Krishna K, Sourdive DJ, Suresh M, Altman JD, et al. Viral Immune Evasion Due to Persistence of Activated T Cells Without Effector Function. J Exp Med (1998) 188(12):2205-13. doi: 10.1084/ jem.188.12.2205

18. Moskophidis D, Lechner F, Pircher H, Zinkernagel RM. Virus Persistence in Acutely Infected Immunocompetent Mice by Exhaustion of Antiviral Cytotoxic Effector T Cells. Nature (1993) 362(6422):758-61. doi: 10.1038/ $362758 \mathrm{a} 0$

19. Speiser DE, Utzschneider DT, Oberle SG, Munz C, Romero P, Zehn D. T Cell Differentiation in Chronic Infection and Cancer: Functional Adaptation or Exhaustion? Nat Rev Immunol (2014) 14(11):768-74. doi: 10.1038/nri3740

20. Wherry EJ, Ha SJ, Kaech SM, Haining WN, Sarkar S, Kalia V, et al. Molecular Signature of CD8+ T Cell Exhaustion During Chronic Viral Infection. Immunity (2007) 27(4):670-84. doi: 10.1016/j.immuni.2007.09.006

21. Zheng C, Zheng L, Yoo JK, Guo H, Zhang Y, Guo X, et al. Landscape of Infiltrating T Cells in Liver Cancer Revealed by Single-Cell Sequencing. Cell (2017) 169(7):1342-56 e16. doi: 10.1016/j.cell.2017.05.035

22. Zhang L, Yu X, Zheng L, Zhang Y, Li Y, Fang Q, et al. Lineage Tracking Reveals Dynamic Relationships of T Cells in Colorectal Cancer. Nature (2018) 564(7735):268-72. doi: 10.1038/s41586-018-0694-x

23. Fourcade J, Sun Z, Pagliano O, Guillaume P, Luescher IF, Sander C, et al. CD8 (+) T Cells Specific for Tumor Antigens can be Rendered Dysfunctional by the Tumor Microenvironment Through Upregulation of the Inhibitory Receptors BTLA and PD-1. Cancer Res (2012) 72(4):887-96. doi: 10.1158/00085472.CAN-11-2637

24. Wherry EJ. T Cell Exhaustion. Nat Immunol (2011) 12(6):492-9. doi: 10.1038/ ni.2035

25. Baitsch L, Baumgaertner P, Devevre E, Raghav SK, Legat A, Barba L, et al. Exhaustion of Tumor-Specific CD8(+) T Cells in Metastases From Melanoma Patients. J Clin Invest (2011) 121(6):2350-60. doi: 10.1172/JCI46102

26. Zippelius A, Batard P, Rubio-Godoy V, Bioley G, Lienard D, Lejeune F, et al. Effector Function of Human Tumor-Specific CD8 T Cells in Melanoma Lesions: A State of Local Functional Tolerance. Cancer Res (2004) 64 (8):2865-73. doi: 10.1158/0008-5472.CAN-03-3066
27. Ahmadzadeh M, Johnson LA, Heemskerk B, Wunderlich JR, Dudley ME, White DE, et al. Tumor Antigen-Specific CD8 T Cells Infiltrating the Tumor Express High Levels of PD-1 and are Functionally Impaired. Blood (2009) 114 (8):1537-44. doi: 10.1182/blood-2008-12-195792

28. Sakuishi K, Apetoh L, Sullivan JM, Blazar BR, Kuchroo VK, Anderson AC. Targeting Tim-3 and PD-1 Pathways to Reverse T Cell Exhaustion and Restore Anti-Tumor Immunity. J Exp Med (2010) 207(10):2187-94. doi: 10.1084/jem.20100643

29. Blank CU, Haining WN, Held W, Hogan PG, Kallies A, Lugli E, et al. Defining 'T Cell Exhaustion'. Nat Rev Immunol (2019) 19(11):665-74. doi: 10.1038/ s41577-019-0221-9

30. Im SJ, Hashimoto M, Gerner MY, Lee J, Kissick HT, Burger MC, et al. Defining CD8+ T Cells That Provide the Proliferative Burst After PD-1 Therapy. Nature (2016) 537(7620):417-21. doi: 10.1038/nature19330

31. Siddiqui I, Schaeuble K, Chennupati V, Fuertes Marraco SA, Calderon-Copete S, Pais Ferreira D, et al. Intratumoral Tcf1(+)PD-1(+)CD8(+) T Cells With Stem-Like Properties Promote Tumor Control in Response to Vaccination and Checkpoint Blockade Immunotherapy. Immunity (2019) 50(1):195-211 e10. doi: 10.1016/j.immuni.2018.12.021

32. Fearon DT, Manders P, Wagner SD. Arrested Differentiation, the SelfRenewing Memory Lymphocyte, and Vaccination. Science (2001) 293 (5528):248-50. doi: 10.1126/science.1062589

33. Jeannet G, Boudousquie C, Gardiol N, Kang J, Huelsken J, Held W. Essential Role of the Wnt Pathway Effector Tcf-1 for the Establishment of Functional CD8 T Cell Memory. Proc Natl Acad Sci U S A (2010) 107(21):9777-82. doi: 10.1073/pnas.0914127107

34. Zhou X, Yu S, Zhao DM, Harty JT, Badovinac VP, Xue HH. Differentiation and Persistence of Memory CD8(+) T Cells Depend on T Cell Factor 1. Immunity (2010) 33(2):229-40. doi: 10.1016/j.immuni.2010.08.002

35. Leong YA, Chen Y, Ong HS, Wu D, Man K, Deleage C, et al. CXCR5(+) Follicular Cytotoxic T Cells Control Viral Infection in B Cell Follicles. Nat Immunol (2016) 17(10):1187-96. doi: 10.1038/ni.3543

36. Chen Z, Ji Z, Ngiow SF, Manne S, Cai Z, Huang AC, et al. TCF-1-Centered Transcriptional Network Drives an Effector Versus Exhausted CD8 T CellFate Decision. Immunity (2019) 51(5):840-55.e5. doi: 10.1016/ j.immuni.2019.09.013

37. Roychoudhuri R, Clever D, Li P, Wakabayashi Y, Quinn KM, Klebanoff CA, et al. BACH2 Regulates CD8(+) T Cell Differentiation by Controlling Access of AP-1 Factors to Enhancers. Nat Immunol (2016) 17(7):851-60. doi: 10.1038/ni.3441

38. Utzschneider DT, Gabriel SS, Chisanga D, Gloury R, Gubser PM, Vasanthakumar A, et al. Early Precursor T Cells Establish and Propagate T Cell Exhaustion in Chronic Infection. Nat Immunol (2020) 21(10):1256-66. doi: 10.1038/s41590-020-0760-Z

39. Yao C, Lou G, Sun HW, Zhu Z, Sun Y, Chen Z, et al. BACH2 Enforces the Transcriptional and Epigenetic Programs of Stem-Like CD8(+) T Cells. Nat Immunol (2021) 22(3):370-80. doi: 10.1038/s41590-021-00868-7

40. Yang CY, Best JA, Knell J, Yang E, Sheridan AD, Jesionek AK, et al. The Transcriptional Regulators Id2 and Id3 Control the Formation of Distinct Memory CD8+ T Cell Subsets. Nat Immunol (2011) 12(12):1221-9. doi: 10.1038/ni.2158

41. Ji Y, Pos Z, Rao M, Klebanoff CA, Yu Z, Sukumar M, et al. Repression of the DNA-Binding Inhibitor Id3 by Blimp-1 Limits the Formation of Memory CD8+ T Cells. Nat Immunol (2011) 12(12):1230-7. doi: 10.1038/ni.2153

42. Gautam S, Fioravanti J, Zhu W, Le Gall JB, Brohawn P, Lacey NE, et al. The Transcription Factor C-Myb Regulates CD8(+) T Cell Stemness and Antitumor Immunity. Nat Immunol (2019) 20(3):337-49. doi: 10.1038/ s41590-018-0311-z

43. Renner K, Bruss C, Schnell A, Koehl G, Becker HM, Fante M, et al. Restricting Glycolysis Preserves T Cell Effector Functions and Augments Checkpoint Therapy. Cell Rep (2019) 29(1):135-50.e9. doi: 10.1016/ j.celrep.2019.08.068

44. Zou D, Dai Y, Zhang X, Wang G, Xiao X, Jia P, et al. T Cell Exhaustion is Associated With Antigen Abundance and Promotes Transplant Acceptance. Am J Transplant (2020) 20(9):2540-50. doi: 10.1111/ajt.15870

45. Martinez GJ, Pereira RM, Aijo T, Kim EY, Marangoni F, Pipkin ME, et al. The Transcription Factor NFAT Promotes Exhaustion of Activated CD8(+) T Cells. Immunity (2015) 42(2):265-78. doi: 10.1016/j.immuni.2015.01.006 
46. Philip M, Fairchild L, Sun L, Horste EL, Camara S, Shakiba M, et al. Chromatin States Define Tumour-Specific T Cell Dysfunction and Reprogramming. Nature (2017) 545(7655):452-6. doi: 10.1038/nature22367

47. Khan O, Giles JR, McDonald S, Manne S, Ngiow SF, Patel KP, et al. TOX Transcriptionally and Epigenetically Programs CD8(+) T Cell Exhaustion. Nature (2019) 571(7764):211-8. doi: 10.1038/s41586-019-1325-x

48. Scott AC, Dundar F, Zumbo P, Chandran SS, Klebanoff CA, Shakiba M, et al. TOX is a Critical Regulator of Tumour-Specific T Cell Differentiation. Nature (2019) 571(7764):270-4. doi: 10.1038/s41586-019-1324-y

49. Alfei F, Kanev K, Hofmann M, Wu M, Ghoneim HE, Roelli P, et al. TOX Reinforces the Phenotype and Longevity of Exhausted T Cells in Chronic Viral Infection. Nature (2019) 571(7764):265-9. doi: 10.1038/s41586-019$1326-9$

50. Yao C, Sun HW, Lacey NE, Ji Y, Moseman EA, Shih HY, et al. Single-Cell RNA-Seq Reveals TOX as a Key Regulator of CD8(+) T Cell Persistence in Chronic Infection. Nat Immunol (2019) 20(7):890-901. doi: 10.1038/s41590019-0403-4

51. Seo H, Chen J, Gonzalez-Avalos E, Samaniego-Castruita D, Das A, Wang YH, et al. TOX and TOX2 Transcription Factors Cooperate With NR4A Transcription Factors to Impose CD8(+) T Cell Exhaustion. Proc Natl Acad Sci U S A (2019) 116(25):12410-5. doi: 10.1073/pnas.1905675116

52. Page N, Lemeille S, Vincenti I, Klimek B, Mariotte A, Wagner I, et al. Persistence of Self-Reactive CD8 $+\mathrm{T}$ Cells in the CNS Requires TOXDependent Chromatin Remodeling. Nat Commun (2021) 12(1):1009. doi: 10.1038/s41467-021-21109-3

53. Chen J, Lopez-Moyado IF, Seo H, Lio CJ, Hempleman LJ, Sekiya T, et al. NR4A Transcription Factors Limit CAR T Cell Function in Solid Tumours. Nature (2019) 567(7749):530-4. doi: 10.1038/s41586-019-0985-x

54. Liu X, Wang Y, Lu H, Li J, Yan X, Xiao M, et al. Genome-Wide Analysis Identifies NR4A1 as a Key Mediator of T Cell Dysfunction. Nature (2019) 567 (7749):525-9. doi: 10.1038/s41586-019-0979-8

55. Quigley M, Pereyra F, Nilsson B, Porichis F, Fonseca C, Eichbaum Q, et al. Transcriptional Analysis of HIV-Specific CD8+ T Cells Shows That PD-1 Inhibits T Cell Function by Upregulating BATF. Nat Med (2010) 16 (10):1147-51. doi: 10.1038/nm.2232

56. Lynn RC, Weber EW, Sotillo E, Gennert D, Xu P, Good Z, et al. C-Jun Overexpression in CAR T Cells Induces Exhaustion Resistance. Nature (2019) 576(7786):293-300. doi: 10.1038/s41586-019-1805-Z

57. Henning AN, Roychoudhuri R, Restifo NP. Epigenetic Control of CD8(+) T Cell Differentiation. Nat Rev Immunol (2018) 18(5):340-56. doi: 10.1038/ nri.2017.146

58. Tough DF, Rioja I, Modis LK, Prinjha RK. Epigenetic Regulation of T Cell Memory: Recalling Therapeutic Implications. Trends Immunol (2020) 41 (1):29-45. doi: 10.1016/j.it.2019.11.008

59. Herndler-Brandstetter D, Ishigame H, Shinnakasu R, Plajer V, Stecher C, Zhao J, et al. KLRG1(+) Effector CD8(+) T Cells Lose KLRG1, Differentiate Into All Memory $\mathrm{T}$ Cell Lineages, and Convey Enhanced Protective Immunity. Immunity (2018) 48(4):716-29.e8. doi: 10.1016/j.immuni. 2018.03.015

60. Youngblood B, Hale JS, Kissick HT, Ahn E, Xu XJ, Wieland A, et al. Effector CD8 T Cells Dedifferentiate Into Long-Lived Memory Cells. Nature (2017) 552(7685):404-+. doi: 10.1038/nature25144

61. Pace L, Goudot C, Zueva E, Gueguen P, Burgdorf N, Waterfall JJ, et al. The Epigenetic Control of Stemness in CD8(+) T Cell Fate Commitment. Science (2018) 359(6372):177-86. doi: 10.1126/science.aah6499

62. Gray SM, Amezquita RA, Guan T, Kleinstein SH, Kaech SM. Polycomb Repressive Complex 2-Mediated Chromatin Repression Guides Effector CD8 (+) T Cell Terminal Differentiation and Loss of Multipotency. Immunity (2017) 46(4):596-608. doi: 10.1016/j.immuni.2017.03.012

63. Durek P, Nordstrom K, Gasparoni G, Salhab A, Kressler C, de Almeida M, et al. Epigenomic Profiling of Human CD4(+) T Cells Supports a Linear Differentiation Model and Highlights Molecular Regulators of Memory Development. Immunity (2016) 45(5):1148-61. doi: 10.1016/j.immuni. 2016.10.022

64. Sen DR, Kaminski J, Barnitz RA, Kurachi M, Gerdemann U, Yates KB, et al. The Epigenetic Landscape of T Cell Exhaustion. Science (2016) 354 (6316):1165-9. doi: 10.1126/science.aae0491
65. Pauken KE, Sammons MA, Odorizzi PM, Manne S, Godec J, Khan O, et al. Epigenetic Stability of Exhausted T Cells Limits Durability of Reinvigoration by PD-1 Blockade. Science (2016) 354(6316):1160-5. doi: 10.1126/ science.aaf 2807

66. Weber EW, Parker KR, Sotillo E, Lynn RC, Anbunathan H, Lattin J, et al. Transient Rest Restores Functionality in Exhausted CAR-T Cells Through Epigenetic Remodeling. Science (2021) 372(6537):eaba1786. doi: 10.1126/ science.aba1786

67. Abdelsamed HA, Zebley CC, Nguyen H, Rutishauser RL, Fan Y, Ghoneim HE, et al. Beta Cell-Specific CD8(+) T Cells Maintain Stem Cell MemoryAssociated Epigenetic Programs During Type 1 Diabetes. Nat Immunol (2020) 21(5):578-87. doi: 10.1038/s41590-020-0633-5

68. Acharya N, Madi A, Zhang H, Klapholz M, Escobar G, Dulberg S, et al. Endogenous Glucocorticoid Signaling Regulates CD8(+) T Cell Differentiation and Development of Dysfunction in the Tumor Microenvironment. Immunity (2020) 53(3):658-71.e6. doi: 10.1016/ j.immuni.2020.08.005

69. Wu H, Huang X, Qiu H, Zhao M, Liao W, Yuan S, et al. High Salt Promotes Autoimmunity by TET2-Induced DNA Demethylation and Driving the Differentiation of Tfh Cells. Sci Rep (2016) 6:28065. doi: 10.1038/srep28065

70. Kleinewietfeld M, Manzel A, Titze J, Kvakan H, Yosef N, Linker RA, et al. Sodium Chloride Drives Autoimmune Disease by the Induction of Pathogenic TH17 Cells. Nature (2013) 496(7446):518-22. doi: 10.1038/nature11868

71. Xu K, Yin N, Peng M, Stamatiades EG, Shyu A, Li P, et al. Glycolysis Fuels Phosphoinositide 3-Kinase Signaling to Bolster T Cell Immunity. Science (2021) 371(6527):405-10. doi: 10.1126/science.abb2683

72. Schietinger A, Greenberg PD. Tolerance and Exhaustion: Defining Mechanisms of T Cell Dysfunction. Trends Immunol (2014) 35(2):51-60. doi: 10.1016/j.it.2013.10.001

73. Richter K, Brocker T, Oxenius A. Antigen Amount Dictates CD8+ T-Cell Exhaustion During Chronic Viral Infection Irrespective of the Type of Antigen Presenting Cell. Eur J Immunol (2012) 42(9):2290-304. doi: 10.1002/eji.201142275

74. Mueller SN, Ahmed R. High Antigen Levels are the Cause of T Cell Exhaustion During Chronic Viral Infection. Proc Natl Acad Sci U S A (2009) 106(21):8623-8. doi: 10.1073/pnas.0809818106

75. Harari A, Dutoit V, Cellerai C, Bart PA, Du Pasquier RA, Pantaleo G. Functional Signatures of Protective Antiviral T-Cell Immunity in Human Virus Infections. Immunol Rev (2006) 211:236-54. doi: 10.1111/j.01052896.2006.00395.x

76. Yamazaki C, Sugiyama M, Ohta T, Hemmi H, Hamada E, Sasaki I, et al. Critical Roles of a Dendritic Cell Subset Expressing a Chemokine Receptor, XCR1. J Immunol (2013) 190(12):6071-82. doi: 10.4049/jimmunol.1202798

77. Uhl FM, Chen S, O'Sullivan D, Edwards-Hicks J, Richter G, Haring E, et al. Metabolic Reprogramming of Donor T Cells Enhances Graft-VersusLeukemia Effects in Mice and Humans. Sci Transl Med (2020) 12(567): eabb8969. doi: 10.1126/scitranslmed.abb8969

78. Zhang D, Jin W, Wu R, Li J, Park SA, Tu E, et al. High Glucose Intake Exacerbates Autoimmunity Through Reactive-Oxygen-Species-Mediated TGF-Beta Cytokine Activation. Immunity (2019) 51(4):671-81.e5. doi: 10.1016/j.immuni.2019.08.001

79. Chen PM, Wilson PC, Shyer JA, Veselits M, Steach HR, Cui C, et al. Kidney Tissue Hypoxia Dictates T Cell-Mediated Injury in Murine Lupus Nephritis. Sci Transl Med (2020) 12(538):eaay1620. doi: 10.1126/scitranslmed.aay1620

80. Doedens AL, Phan AT, Stradner MH, Fujimoto JK, Nguyen JV, Yang E, et al. Hypoxia-Inducible Factors Enhance the Effector Responses of CD8(+) T Cells to Persistent Antigen. Nat Immunol (2013) 14(11):1173-82. doi: 10.1038/ ni.2714

81. Eil R, Vodnala SK, Clever D, Klebanoff CA, Sukumar M, Pan JH, et al. Ionic Immune Suppression Within the Tumour Microenvironment Limits T Cell Effector Function. Nature (2016) 537(7621):539-43. doi: 10.1038/nature19364

82. Vodnala SK, Eil R, Kishton RJ, Sukumar M, Yamamoto TN, Ha NH, et al. T Cell Stemness and Dysfunction in Tumors are Triggered by a Common Mechanism. Science (2019) 363(6434):eaau0135. doi: 10.1126/science.aau0135

83. Braun DA, Street K, Burke KP, Cookmeyer DL, Denize T, Pedersen CB, et al. Progressive Immune Dysfunction With Advancing Disease Stage in Renal Cell Carcinoma. Cancer Cell (2021) 39(5):632-48.e8. doi: 10.1016/j.ccell.2021.02.013 
84. Azizi E, Carr AJ, Plitas G, Cornish AE, Konopacki C, Prabhakaran S, et al. Single-Cell Map of Diverse Immune Phenotypes in the Breast Tumor Microenvironment. Cell (2018) 174(5):1293-308.e36. doi: 10.1016/ j.cell.2018.05.060

85. Li H, van der Leun AM, Yofe I, Lubling Y, Gelbard-Solodkin D, van Akkooi ACJ, et al. Dysfunctional CD8 T Cells Form a Proliferative, Dynamically Regulated Compartment Within Human Melanoma. Cell (2020) 181(3):747. doi: 10.1016/j.cell.2020.04.017

86. Galletti G, De Simone G, Mazza EMC, Puccio S, Mezzanotte C, Bi TM, et al. Two Subsets of Stem-Like CD8(+) Memory T Cell Progenitors With Distinct Fate Commitments in Humans. Nat Immunol (2020) 21(12):1552-62. doi: 10.1038/s41590-020-0791-5

87. Sekine T, Perez-Potti A, Nguyen S, Gorin JB, Wu VH, Gostick E, et al. TOX is Expressed by Exhausted and Polyfunctional Human Effector Memory CD8(+) T Cells. Sci Immunol (2020) 5(49):eaba7918. doi: 10.1126/sciimmunol.aba7918

88. Beltra JC, Manne S, Abdel-Hakeem MS, Kurachi M, Giles JR, Chen Z, et al. Developmental Relationships of Four Exhausted CD8(+) T Cell Subsets Reveals Underlying Transcriptional and Epigenetic Landscape Control Mechanisms. Immunity (2020) 52(5):825-41.e8. doi: 10.1016/j.immuni.2020.04.014

89. Kao C, Oestreich KJ, Paley MA, Crawford A, Angelosanto JM, Ali MA, et al. Transcription Factor T-Bet Represses Expression of the Inhibitory Receptor PD-1 and Sustains Virus-Specific CD8+ T Cell Responses During Chronic Infection. Nat Immunol (2011) 12(7):663-71. doi: 10.1038/ni.2046

90. Sawinski D, Trofe-Clark J, Leas B, Uhl S, Tuteja S, Kaczmarek JL, et al. Calcineurin Inhibitor Minimization, Conversion, Withdrawal, and Avoidance Strategies in Renal Transplantation: A Systematic Review and Meta-Analysis. Am J Transplant (2016) 16(7):2117-38. doi: 10.1111/ajt.13710

91. Lipson EJ, Bagnasco SM, Moore JJr., Jang S, Patel MJ, Zachary AA, et al. Tumor Regression and Allograft Rejection After Administration of Anti-PD1. N. Engl J Med (2016) 374(9):896-8. doi: 10.1056/NEJMc1509268

92. Murakami N, Mulvaney P, Danesh M, Abudayyeh A, Diab A, Abdel-Wahab $\mathrm{N}$, et al. A Multi-Center Study on Safety and Efficacy of Immune Checkpoint Inhibitors in Cancer Patients With Kidney Transplant. Kidney Int (2020) 100 (1):196-205. doi: 10.1016/j.kint.2020.12.015
93. Levitsky J, Burrell BE, Kanaparthi S, Turka LA, Kurian S, Sanchez-Fueyo A, et al. Immunosuppression Withdrawal in Liver Transplant Recipients on Sirolimus. Hepatology (2020) 72(2):569-83. doi: 10.1002/hep.31036

94. Fribourg M, Anderson L, Fischman C, Cantarelli C, Perin L, La Manna G, et al. T-Cell Exhaustion Correlates With Improved Outcomes in Kidney Transplant Recipients. Kidney Int (2019) 96(2):436-49. doi: 10.1016/ j.kint.2019.01.040

95. Wu J, Zhang H, Shi X, Xiao X, Fan Y, Minze LJ, et al. Ablation of Transcription Factor IRF4 Promotes Transplant Acceptance by Driving Allogenic CD4(+) T Cell Dysfunction. Immunity (2017) 47(6):1114-28.e6. doi: 10.1016/j.immuni.2017.11.003

96. Miller ML, McIntosh CM, Wang Y, Chen L, Wang P, Lei YM, et al. Resilience of T Cell-Intrinsic Dysfunction in Transplantation Tolerance. Proc Natl Acad Sci U S A (2019) 116(47):23682-90. doi: 10.1073/pnas.1910298116

97. Zeng F, Chen Y, Remis J, Shekhar M, Phillips JC, Tajkhorshid E, et al. Structural Basis of Co-Translational Quality Control by ArfA and RF2 Bound to Ribosome. Nature (2017) 541(7638):554-7. doi: 10.1038/nature21053

Conflict of Interest: The authors declare that the research was conducted in the absence of any commercial or financial relationships that could be construed as a potential conflict of interest.

Publisher's Note: All claims expressed in this article are solely those of the authors and do not necessarily represent those of their affiliated organizations, or those of the publisher, the editors and the reviewers. Any product that may be evaluated in this article, or claim that may be made by its manufacturer, is not guaranteed or endorsed by the publisher.

Copyright (c) 2021 Gonzalez, Zou, Gu and Chen. This is an open-access article distributed under the terms of the Creative Commons Attribution License (CC BY). The use, distribution or reproduction in other forums is permitted, provided the original author(s) and the copyright owner(s) are credited and that the origina publication in this journal is cited, in accordance with accepted academic practice. No use, distribution or reproduction is permitted which does not comply with these terms. 